\title{
İşyerindeki Dışlanmanın, İşyerindeki Sapkın Davranışlar Üzerindeki Etkisi: Personelin Düzenleyici Odağının Rolü* \\ (The Influence of Workplace Exclusion on Workplace Deviance Behaviors: The Role of Employees' Regulatory Focus)
}

\author{
Mahmut AKIN iD a Mahmut ÖZDEVECİOĞLU (iD b \\ a Yozgat Bozok Üniversitesi, Yozgat, Türkiye. mahmut.akin@bozok.edu.tr \\ b Emekli Öğretim Üyesi, Yönetim Danışmanı, Türkiye. mozdevecioglu@hotmail.com
}

\section{MAKALE BİLGİṠ \\ Anahtar Kelimeler: \\ İşyerinde Dişlanma Sapkın Davranışlar Düzenleyici Odak}

Gönderilme Tarihi 31 Mayıs 2021

Revizyon Tarihi 1 Kasım 2021

Kabul Tarihi 10 Kasım 2021

Makale Kategorisi:

Araştırma Makalesi

\section{ÖZET}

Amaç - Bu çalışmanın amacı, çalışanların dışlanmışlıklarının onların sapkın davranışları üzerindeki etkisini ve bu etkide düzenleyici odağın aracılık rolünü belirlemektir.

Yöntem - Araştırma Türkiye' de ve Kayseri ilinde 278 sağlık çalışanı ile gerçekleştirilmiştir. Araştırma verileri anket yöntemiyle ve gönüllülük esasına göre toplanmıştır. Araştırma verilerinin değerlendirilebilmesi için istatistik paket programından yararlanılmıştır. Veriler değerlendirilirken öncelikle araştırma değişkenlerinin ortalamaları hesaplanmış, devamında değişkenler arasındaki ilişkilerin ortaya çıkarılması için korelasyon analizi ve aracılık etkisinin değerlendirilebilmesi için regresyon analizi yapılmıştır. Çalışmada düzenleyici odak, önleme ve ödül olmak üzere iki alt boyutta ele alınmıştır. Dışlanmışlık ise arkadaşları tarafından dışlanma ve yöneticileri tarafından dışlanma olarak iki alt boyutta incelenmiştir.

Bulgular - Araştırma sonuçlarına göre, dışlanmanın sapkın davranışları artırdı ğı, önleyici odağın sapkın davranışlar üzerinde pozitif, ödül odağın ise sapkın davranışlar üzerinde negatif etkiye sahip olduğu belirlenmiştir. Çalışmada ödül odak ile önleme odak arasında negatif yönlü bir ilişki bulunduğu da tespit edilmiştir. Ayrıca, hem önleme hem de ödül odağın, dışlanmışlığın sapkın davranışlar üzerindeki pozitif etkisinde anlamlı bir aracılık rolüne sahip olduğu belirlenmiştir

Tartışma - Çalışmada, örgütlerde dışlanmanın sebep olabileceği olumsuz sonuçlara dikkat çekilmiştir. Örgütlerde dışlanmanın oluşmaması için gerekli tedbirler alınırsa ortaya çıkabilecek olumsuzlukların engellenmesi sağlanabilir. Alanyazında, dışlanma, sapkın davranış ve düzenleyici odak konularını birlikte ele alan bir çalışma bulunmadığından elde edilen sonuçların alanyazına katkı sağlaması beklenmektir.

ARTICLE INFO ABSTRACT

\section{Keywords:}

Workplace exclusion Deviance behaviors Regulatory focus

Received 31 May 2021

Revised 1 November 2021

Accepted 10 November 2021

Article Classification: Research Article
Purpose - The aim of this study was to determine the effect of exclusion of employees on their deviant behaviors and mediating effect of regulatory focus on this effect.

Design/methodology/approach- The study was carried out on a total of 273 healthcare workers in Kayseri province of Turkey. The research data were collected by survey method and on a voluntary basis. Statistics package program was used to evaluate the research data. While evaluating the data, the averages of the research variables were calculated first, and then the correlation analysis to reveal the relationships between the variables and the regression analysis to evaluate the mediation effect. In the study, two sub-dimensions are discussed as regulatory focus, prevention and reward. Exclusion, on the other hand, was examined in two sub-dimensions as exclusion by friends and exclusion by managers.

Findings - According to the results of the research, it was determined that exclusion increased deviant behaviors, preventive focus had a positive effect on deviant behaviors, and reward focus had a negative effect on deviant behaviors. In the study, it was also determined that there is a negative relationship between reward focus and prevention focus. . In addition, it was determined that both prevention and reward focus had a significant mediating role in the positive effect of exclusion on deviant behaviors.

Discussion - In the study, attention was drawn to the negative consequences of exclusion in organizations. If necessary measures are taken to prevent exclusion in organizations, it can be ensured that the negative consequences that may arise are prevented. Since there is no study in the literature that deals with exclusion, deviant behavior and regulatory focus together, it is expected that the results obtained will contribute to the literature.

\footnotetext{
${ }^{1} \mathrm{Bu}$ çalışma 2012 yılında Polonya'da gerçekleştirilen “The 12th International Academy of Management and Business (IAMB) Conference” kongresinde bildiri olarak sunulmuştur. Önerilen Atıf/Suggested Citation
}

Akın, M., Özdevecioğlu, M. (2021). İşyerindeki Dışlanmanın, İşyerindeki Sapkın Davranışlar Üzerindeki Etkisi: Personelin Düzenleyici Odağının Rolü, İşletme Araştırmaları Dergisi, 13 (4), 2916-2926. 


\section{Giriş}

Bu çalışmada, işyerinde dışlanmanın, çalışanların sapkın davranışlarına etkisi tartışılmaktadır. İşyerindeki dışlanma bağımsız, sapkın davranışlar ise bağımlı değişken olarak kabul edilmiştir. Çalışanların düzenleyici odağı da aracı değişken olarak değerlendirilmiştir. İşyerinde dışlanma, üzüntü, yalnızlık, kıskançlık, suçluluk, utanç, sosyal kaygı gibi bir dizi olumsuz duygusal durumla ilgilidir. Bazı araştırmalar, dışlanan kişilerin, dışlayanlarla gelecekteki temastan kaçınma arzusuna sahip olduğunu (Hitlan ve Noel, 2009: 479), toplum yanlısı davranışlarının azaldığını, davranışlarını düzenleme yeteneğinin azaldığını ve bilişsel işlevselliklerinin bozduğunu göstermiştir. (Baumeister vd., 2005: 589). Dışlama, çalışanın kişisel çıkarlarına hizmet eden kısa vadeli davranışlarının artmasına ve örgütün gelecekteki başarısına odaklanan uzun vadeli davranışlarının azalmasına sebep olabilir (Hitlan ve Noel, 2009: 479).

Bu çalışmanın bağımlı değişkeni olan sapkın davranışlar Robinson ve Bennett (1995: 556) tarafından tanımlanmıştır. Robinson ve Bennett sapkın davranışları, önemli örgütsel normları ihlal eden ve bunu yaparken bir örgütü, üyelerini veya her ikisinin refahını tehdit eden, örgüt üyelerinin gönüllü davranışları olarak tanımlamıştır. Sapkın davranışlar, söylenti çıkarmak ve iş arkadaşlarını utandırmak gibi küçük eylemlerden hırsızlık ve sabotaj gibi ciddi eylemlere kadar farklı biçimlerde karşımıza çıkabilir.

Çalışanların düzenleyici odağı bu çalışmadaki aracı değişkendir. Düzenleyici odak kavramı, psikolojinin çeşitli alanlarındaki araştırmacılardan giderek artan bir ilgi görmektedir. Düzenleyici odağın çeşitli davranışlar ve motivasyon süreçleriyle ilişkisi belirlenmiştir. Bu kavram alanyazında Higgins tarafından ayrıntılı bir şekilde tartışılmıştır (Brenninkmeijer, vd., 2010: 711; Uskul vd., 2009: 506). Higgins'e göre, motivasyon süreçlerinin açıklanmasında memnuniyet ilkesi çok baskın olmuş ve bu süreçlerin temel ilkeleri göz ardı edilmiştir. Düzenleyici odak teorisinde Higgins, öz düzenlemede iki ayrı düzenleyici odağı tanımlar. Ödül odaklı bireyler, öncelikle ideal benliklerini, umutlarını ve özlemlerini gerçekleştirmeye çalışırlar. Büyüme ve gelişme olasılıklarına odaklanırlar ve olumlu sonuçları en üst düzeye çıkarmak için çabalarlar. Aksine, önleme odaklı bireyler esas olarak yükümlülüklerini ve sorumluluklarını yerine getirmekle ilgilenirler. Güvenlik için gayret gösterirler ve olumsuz sonuçları en aza indirmeyi amaçlarlar.

$\mathrm{Bu}$ çalışmanın temel amacı örgütlerde dışlanmanın sapkın davranışlar üzerindeki etkisini ve bu etkide düzenleyici odağın aracılık rolünü belirlemektir. İşyerinde karşılaşılan sapkın davranışların işletmelere çok ağır bir bedel ödettiği bilinmektedir. (Dunlop ve Lee, 2004: 69). Bu bedelin ödenmemesi için sapkın davranışlara nelerin sebep olduğunun belirlenmesi ve önleyici tedbirlerin alınması büyük önem taşımaktadır. Bu çalışmada sapkın davranışların ortaya çıkmasında önemli bir etkisi olduğu düşünülen dışlanma ve aracılık rolü olduğu düşünülen düzenleyici odak ele alınmıştır. Alanyazında dışlanma, sapkın davranış ve düzenleyici odağı birlikte ele alan bir çalışmaya rastlanmadığı için çalışmanın alanyazına katkı sağlaması beklenmektedir.

\section{Kavramsal Çerçeve}

\section{1. İşyerinde Dışlanma}

İşyerinde dışlama, bir elemana karşı çalışma ortamında başka bir birey veya grup tarafından uygulanan, iletişimin kesilmesi veya sınırlandırılması, o kişiden uzak durulması, kişinin ihmal edilerek toplum dışına itilmesi şeklinde gerçekleşir (Hitlan vd., 2006: 217; Hitlan ve Noel, 2009: 478). Dışlanma reddedilmekten farklıdır. Reddetmekte, kesin ve katı bir şekilde kişiyle iletişimin koparılması söz konusuyken, dışlamada kişiyle iletişim tamamen koparılmak yerine en alt düzeye indirilir (Braas ve Scott, 2007:16). Dışlama söz konusu olduğunda kişi ayrıca, sözlerinin dinlenmemesi, önemli bilgilerden mahrum edilme, önemli faaliyetlere davet edilmeme, önemli etkinliklere katılımın engellenmesi gibi davranışlara da maruz kalabilirler (Braas ve Scott, 2007:19). Dışlama davranışı basit bir olay gibi görülmemelidir. Dışlama örgütün yapı ve işleyişi üzerinde derin etkiler oluşturabilir. Dışlama davranışı çoğu araştırmacı tarafından bir çeşit işyeri zorbalığı olarak kabul edilmektedir (Hitlan vd., 2006: 218).

Örgütlerde dışlanma durumu, insanlarda doğuştan gelen bir ihtiyaç olan, bir gruba ait olma, kabul edilme, destekleyici ilişkiler kurma ve sürdürme ihtiyaçlarının karşılanmasını engellemektedir (Braas ve Scott, 2007:3; Hitlan ve Noel, 2006: 479). Dışlanma kişileri sosyal etkileşimden mahrum bıraktığı için önemli düzeyde rahatsızlık vericidir (Braas ve Scott, 2007:9). Ait olmaktan ve sosyal etkileşimden mahrum bırakılan insanların 
bu durumdan olumsuz yönde etkilendikleri ve bu duruma karşı tepki niteliğinde davranışlara yöneldikleri görülmektedir.

Yapılan bir araştırmaya göre, dışlanmaya maruz kalan kişilerin, öz saygılarının zedelendiği ve psikolojik sağlıklarının bozulduğu görülmüştür. Dışlanan kişilerin ayrıca sapkın davranışlarda bulundukları belirlenmiştir. Bu kişiler dışlanmalarına karşılık, intikam almak amacıyla, saldırgan davranışlar göstermekte, performanslarını düşürmekte, ödülleri ve eğitim programlarını reddetmekte, örgütsel vatandaşlık davranışlarını azaltmaktadırlar (Braas ve Scott, 2007:36; Hitlan ve Noel, 2009: 479; Hitlan vd., 2006: 218).

Dışlanan kişilerin ayrıca yoğun bir şekilde üzüntü, endişe, yalnızlık, kıskançlık, suçluluk, utanç, sıkıntı gibi olumsuz duygular yaşadıkları da belirlenmiştir. Bu şekilde olumsuz duygular içerisinde olan kişilerin kendisini dışlayanlarla geleceğe yönelik olarak tüm bağlantılarını kopardıkları ve örgüte yarar sağlayabilecek tüm faaliyetleri bir kenara bırakarak yalnızca kendi çıkarlarını düşünmeye başladıkları görülmüştür (Hitlan ve Noel, 2009: 479). Dışlanmadan dolayı insanların uzun süreli olumsuz duygular içerisinde olmalarının fiziksel ve ruhsal sağlıklarını da olumsuz yönde etkileyeceği bilinmektedir (Huffman,1994: 424; Yperen, 2003: 1875). Dolayısıyla dışlanmanın doğrudan ve dolaylı olumsuz etkileri görülebilenden çok daha derindir.

\section{2. İsyerinde Sapkın Davranışlar}

İşyerinde sapkın davranışlar, örgüt mensuplarınca kasıtlı olarak gerçekleştirilen, örgüt kurallarını ihlal ederek örgüte ve örgüt üyelerine zarar veren davranışlardır (Brown ve Trevino, 2006: 954). Başka bir tanıma göre sapkın davranışlar, örgüt üyelerince bilinçli olarak gerçekleştirilerek örgütün yapı ve işleyişini tehdit eden davranışlardır (Dunlop ve Lee, 2004:69). İşyerinde sapkın davranışlar, personelde yeterli düzeyde örgütsel bağlılı̆̆ın oluşturulamamasından veya yeterli sosyal kontrolün yapılamamasından kaynaklanabilir (Raelin, 1994: 483). Sapkın davranışların bir diğer sebebi personelin sahip olduğu kişilik özellikleridir. Yapılan bir araştırmada, düşük uyumluluk, düşük vicdanlılık ve dişadönüklük aynı anda bir kişide bulunursa bu durumun sapkın davranışları artırdığı belirlenmiştir (Witt ve Andrews, 2006: 3). Ayrıca örgütlerde personelin yaşadıkları çatışmalar da elemanların kolaylıkla sapkın davranışlara yönelmelerine sebep olabilir (Raelin, 1994: 483).

İşyerinde sapkın davranışlar oldukça yaygın bir problem olup, örgütün yapı ve işleyişine yönelik önemli bir tehdittir. Sapkın davranışlar çalışma arkadaşlarına veya astlara yönelik olarak gerçekleştirilebilir. Sapkın davranışlar örgütte rahatsız edici bir ortamın oluşmasına sebep olur. Dolayısıyla örgütte, devamsızlık, işten ayrılma niyeti, iş tatminsizliği ve stresin artması ve bu yüzden de verimliliğin düşmesi beklenir (Witt ve Andrews, 2006: 1). İşyerinde sapkın davranışlar, asılsız söylentiler çıkarmak gibi nispeten basit eylemlerden, işyerine yönelik olarak sabotaj düzenlemek ve hırsızlık yapmak gibi çok ağır suçlara kadar bir yelpazede karşımıza çıkabilir. Saldırgan davranışlar, kasıtlı olarak kaynakları israf etme, başka birinin suçunu çalışma arkadaşlarına yükleme, çalışma arkadaşlarını taciz etme, hakaret etme, tehdit etme, yöneticinin emirlerini önemsememe, örgüt mallarına zarar verme, işini yavaş ve özensiz yapma, hastalık bahanesiyle işe gelmeme, işyerine ait sırları saklamama, düşük performans gösterme, devamsızlık, iş yerinde alkol veya uyuşturucu kullanma şeklinde olabilir (Brown ve Trevino, 2006: 954; Dunlop ve Lee, 2004: 69; Raelin, 1994: 483).

Çoğu araştırmacıya göre işyerinde sapkın davranışlar örgüt performansına yönelik önemli bir tehdittir. Amerika birleşik devletlerinde işyerlerindeki hırsızlığın bedeli yıllık 120 milyar dolara ulaşmaktadır. Sabotajların da bu derecede ciddi bir bedele ulaştı̆̆ı tahmin edilmektedir. Eğer işyerlerindeki sapkın davranışlar önlenebilirse bu derecede ciddi maliyetlerden kurtulmak mümkün olabilir (Dunlop ve Lee, 2004: 69).

\section{3. Çalışanın Düzenleyici Odağı}

Higgins insanların kendilerine keyif veren şeylere yaklaşmalarını ve acı veren şeylerden uzaklaşmalarını içeren temel motivasyon prensibini genişleterek düzenleyici odak yaklaşımını geliştirmiştir (Brenninkmeijer vd., 2010: 711; Uskul vd., 2009: 506). Düzenleyici odak yaklaşımının “ödül odaklı" ve "önleme odaklı" olmak üzere iki farklı boyutu vardır. Bazı insanlar davranışlarına ödül odakı bir anlayışla yön verirken, bazıları da önleme odaklı yön vermektedir. Ödül odaklı düşünen insanları motive eden şey, ideallerindeki benliklerine umutlarına isteklerine ve amaçlarına ulaşabilmektir. Bu kişiler gelişme fırsatlarına odaklanırlar ve pozitif çıtıları en yüksek düzeye çıkarabilmek için yoğun gayret gösterirler (Brenninkmeijer vd., 2010: 711). Engelleme odaklı düşünen insanları motive eden şey ise emniyet ihtiyacıdır. Bu insanlar, görevlerini ve 
sorumluluklarını yerine getirerek mevcut durumlarından, olmaları gereken duruma doğru hareket etmeye çalışırlar böylece de kaybetmekten korunmaya ve negatif çıtıları en aza indirmeye çalışırlar (Wu vd., 2008: 2). Hata yapmanın maliyetinin neler olabileceği kişinin zihninde önemli bir yer işgal etmektedir. Düzenleyici odak yaklaşımının duygularla da ilişkisi vardır. Ödül odaklı yaklaşıma sahip insanların genellikle pozitif duygulara sahip oldukları, önleme odaklı yaklaşıma sahip insanların ise genellikle negatif duygulara sahip oldukları görülmüştür. İnsanların iki farklı düzenleyici odaktan birisini benimsemelerinde kültürün önemli bir etkisi vardır (Uskul vd., 2009: 510). Bireyci kültürlerin egemen olduğu ülkelerde insanların amaçlarına ve başarılarına yönelmeleri onların ödül odaklı yaklaşıma sahip olmalarına sebep olmaktadır. Yani kaçmak istedikleri negatif çıtılara değil, ulaşmak istedikleri pozitif çıktılara odaklanmaktadırlar. Diğer taraftan, toplumcu kültürel yapının egemen olduğu ülkelerde ise insanlar için grup üyeliği büyük önem taşır. Kişi gruba uyum sağlamak ve grubun beklentilerini karşlamak için üzerine düşen görevleri titizlikle gerçekleştirmeye çalışır. Bu şartlar altında kişilerin önleme odaklı bir yaklaşıma sahip oldukları görülmektedir. Böylece kişiler ulaşmaya çalıştıkları pozitif çıktılara odaklanmaktansa, kaçınmaya çalıştıkları negatif çıktılara odaklanmaktadırlar.

Yapılan araştırmalarda insanların ödül odaklı olmalarının birtakım yararlarının, önleme odaklı olmalarının da bazı zararlarının bulunduğu belirlenmiştir (Brenninkmeijer vd., 2010: 721; Wu vd., 2008: 2; Uskul vd., 2009: 510). Bu araştırmalar aşağıda sıralanmaktadır

- Ödül odaklı yaklaşımın, engelleme odaklı yaklaşıma kıyasla, ulaşılmaya çalışılan unsurlara yönelik olarak pozitif tutumların gelişmesine daha fazla katkı sağladığı belirlenmiştir.

- Ödül odaklı insanların daha yüksek düzeyde iş tatminine örgütsel bağlılığa sahip oldukları görülmüştür.

- Önleme odaklı insanların daha fazla duygusal tükenmişlik yaşadıkları belirlenmiştir.

- Örgütlerde ödül odaklı yaklaşım geçerliyse bu durumda personelin yenilikçiliği, yaratıcılığı ve girişimciliğinin bu durumdan olumlu yönde etkilendiği görülmüştür.

- Örgütlerde önleme odaklı yaklaşımların, muhafazakâr bir anlayış ortaya çıkardığı ve böylece yaratıcılığın azalmasına sebep olduğu belirlenmiştir.

Her ne kadar yukarıda sıralanmış olan araştırma sonuçları ödül odaklı yaklaşımın yararlarına, önleme odaklı yaklaşımın da zararlarına işaret etse de, bu konuda farklı bir bakış açısı daha mevcuttur (Brenninkmeijer, vd., 2010: 711). Bu bakış açısına göre ödül odaklı yaklaşımın her zaman için yararlı, önleme odaklı yaklaşımının ise her zaman için zararlı olduğunu söylemek mümkün değildir. Ödül veya önleme yaklaşımının yararları kişinin yaptığı işin özelliğine bağlı olarak ortaya çıkar. Buna düzenleyici uyum denir. Kişinin işi, güvenliğin ve takibin hayati derecede önemli olduğu bir alandaysa (itfaiye gibi) personel önleyici odak yaklaşımının faydasını görebilir. İşletmelerin pazarlama bölümlerinde ise personelin ödül odaklı yaklaşımı yarar sağlayacaktır. Bazı durumlarda ise aynı anda iki yaklaşımın benimsenmesi ideal olacaktır. Girişimciler buna örnek verilebilir. Girişimcilikte yenilikçilik ve yaratıcılık yönünde ödül odaklı bir yaklaşımın yararı olacağı gibi, yeni fikirlerin elenmesi konusunda da önleyici odaklı yaklaşım işe yarayacaktır. Sonuç olarak, ödül odaklı yaklaşımın amaçlara ulaşılması önemli olduğunda, önleme odaklı yaklaşımın ise emniyet ihtiyacının yüksek olduğu durumlarda fayda sağlayacağı ifade edilebilir (Oyserman vd., 2007: 506).

Araştırma değişkenleri hakkında bilgi verildikten sonra bu kısımda saha çalışmasında neler yapıldığı, araştırma verilerinin nasıl toplandığı ve analiz edildiği, hangi sonuçlara ulaşıldığı hakkında bilgi verilecektir.

\section{Yöntem}

\subsection{Araştırmanın Modeli ve Hipotezler}

Araştırma modelinde iki alt boyutuyla dışlanmanın sapkın davranışlar üzerindeki etkisinde ödül odağın ve önleyici odağın aracılık rolü gösterilmektedir. 


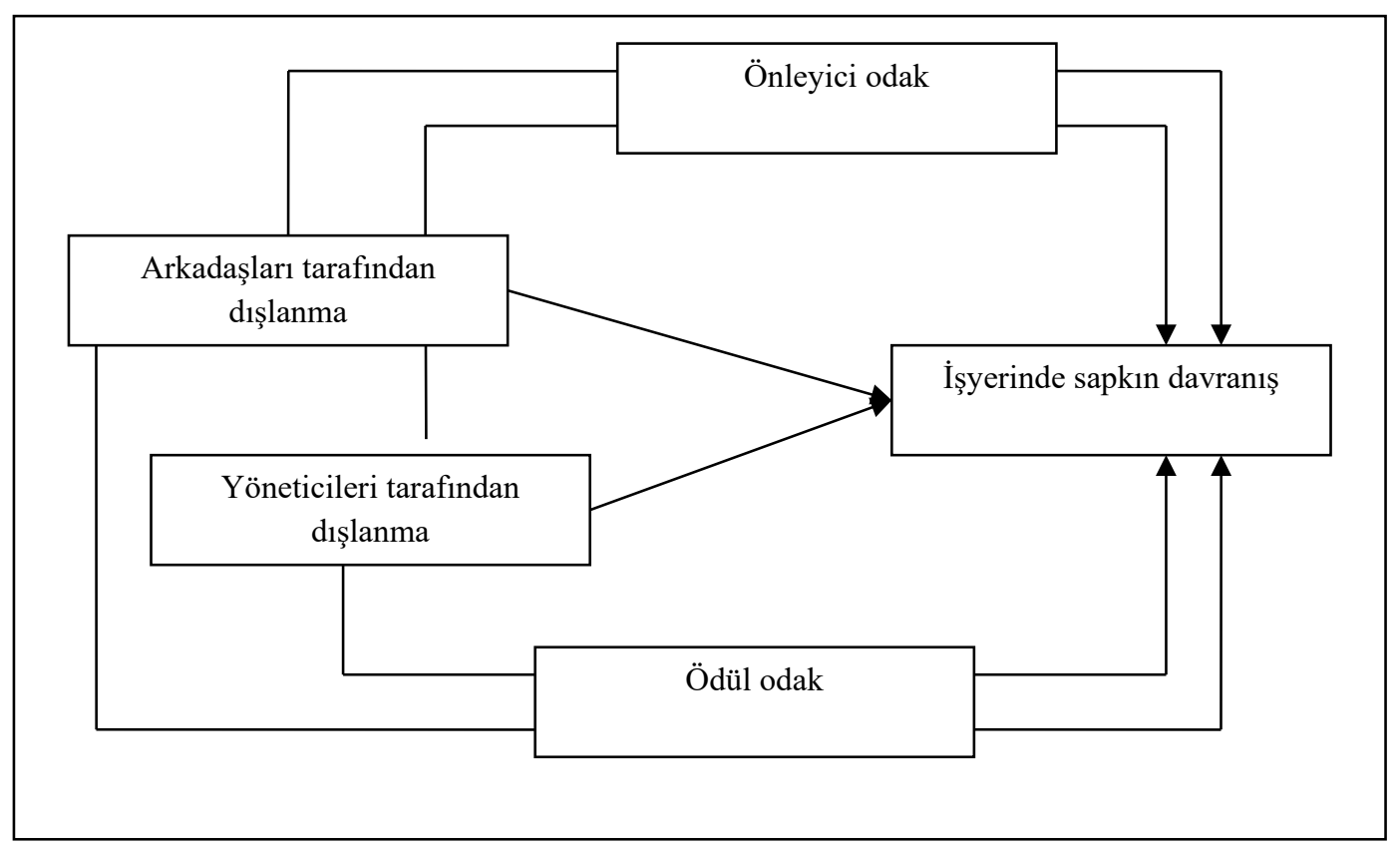

Şekil 1: Araştırma Modeli

\subsection{Evren ve Örneklem}

Araştırma Kayseri'de faaliyet gösteren kamu ve özel sektör hastanelerinde çalışan sağlık personeli ile yürütülmüştür. Çalışmada doktorlar kapsam dışında tutulmuştur. Araştırmanın evreninde 7500 sağlik çalışanı bulunmaktadır. Araştırma kapsamında, kolayda örnekleme metoduyla 320 anket formu dağıtılmış, 293'ü toplanabilmiştir (Şahin ve Kartal, 2011: 155). Toplanan anketlerden 15'i çeşitli nedenlerle geçersiz kabul edilmiştir. Sonuç olarak 278 anket formu değerlendirilmek üzere kabul edilmiştir. Elde edilmiş olan anket sayısı, evreni yaklaşık olarak temsil etmektedir (Kurtuluş, 1998: 236).

\subsection{Veri Toplama Araçları}

Veriler geliştirilen bir anket formu aracılığı ile 2012 yılında toplanmıştır. Anket formu dört bölümden oluşmaktadır. Birinci bölümde çalışanların demografik özelliklerini belirlemeye yönelik sorular bulunmaktadır. Diğer bölümlerde ise araştırmanın üç değişkenine ilişkin ölçekler kullanılmıştır. Ölçekler şunlardır:

3.3.1. İşyerinde Dışlanma Ölçeği: Hitlan ve Noel (2009: 502) tarafından geliştirilen işyerinde Dışlama Ölçeği, katılımcılardan kurumlarında son 12 ay boyunca hangi sıklıkla, farklı türden dışlayıcı davranışlar yaşadıklarını belirtmelerini isteyen 17 maddelik bir öz bildirim ölçeğidir. Ölçek üç alt boyuttan oluşmaktadır. Ancak bu çalışmada ölçeğin iki alt boyutu kullanılmıştır. Birinci alt boyut 7 ifadeden oluşmaktadır ve çalışanın iş arkadaşları tarafından dışlanmasını ölçmektedir. İkinci alt boyut 5 ifadeden oluşmaktadır ve çalışanların yöneticileri tarafından dışlanmasını ölçmektedir. Tüm cevaplar, 1 (asla) ile 5 (Her zaman) arasında değişen 5 puanlık Likert ölçeği ile elde edilmiştir. Yüksek puanlar, algılanan dışlanma düzeylerinin daha yüksek olduğunu göstermektedir. Ölçeğin Cronbach alfa iç tutarlılık katsayısı toplam 0.88 olarak bulunmuştur. İş arkadaşları tarafından dışlanma ölçeğinin iç tutarlılığı 0.91 , yöneticileri tarafından dışlanma ölçeğinin iç tutarlılığ

3.3.2. İşyerinde Sapkın Davranışlar Ölçeği: İşyerindeki sapkın davranışlar, Robinson ve Bennett'in (1995: 571) 12 örgütsel sapma maddesinden oluşan ölçeği ile değerlendirilmiştir. (örneğin; "izin alınmadan işyerinden bir alet alınması"). Katılımcıların, her bir davranışa ne ölçüde katıldıklarını 5 puanlık bir ölçekte derecelendirmeleri istenmiştir ( 1 = Hiçbir zaman, 5 = Her zaman). Çalışmada sapkın davranışlar ölçeğinin Cronbach alfa iç tutarlılık katsayısı 0.86 olarak hesaplanmıştır.

3.3.3. Düzenleyici Odak Ölçeği: Düzenleyici odak, Lockwood tarafından geliştirilen, iki boyutu bulunan ve 10 ifadeli bir ölçekle değerlendirilmiştir. Ölçek, ödül odak ve önleme odak olmak üzere iki alt boyuttan oluşmaktadır (Elsamen, 2011: 88). Ölçekte "Kazanç sağlamaktan ziyade, kayıpları önlemeye çalışıyorum" şeklinde 5 ifade önleyici odağı, “Gelecekte ulaşmayı ümit ettiğim başarılara odaklanırım." şeklinde 5 ifade de ödül odağı 
ölçmeye yöneliktir. Ölçek $5^{\prime}$ li likert tipi ( $1=$ Kesinlikle Katılmıyorum, $5=$ Kesinlikle Katıllyorum) ile hazırlanmıştır. Çalışmada ödül odak ölçeğinin Cronbach alfa iç tutarlılık katsayısı 0.92, önleme odak ölçeğinin iç tutarlılık katsayısı ise 0.89 olarak hesaplanmıştır.

\section{Analiz ve Bulgular}

Araştırma verileri gönüllülük esasına göre toplanmıştır. Cevaplanmış anketler tutarlılık açısından değerlendirilmiş, ciddi bir şekilde doldurulmadığı anlaşılanlar araştırma kapsamı dışında tutulmuştur. Araştırma verilerinin değerlendirilebilmesi için istatistik paket programından yararlanılmıştır. Veriler değerlendirilirken öncelikle araştırmaya katılanların demografik özellikleri belirlenmiş, sonra araştırma değişkenlerinin ortalamaları hesaplanmış, devamında korelasyon analizi ve aracılık etkisinin değerlendirilebilmesi için regresyon analizi yapılmıştır.

\subsection{Araştırmaya Katılanların Demografik Özellikleri}

Araştırmaya katılanların \% 79.1'i kadın ve \% 20.1'i erkek sağlık çalışanından oluşmaktadır. Yaş ortalaması $30.5^{\prime}$ dir. Evlilerin oranı \% 65, bekârların oranı \% 30 ve diğerlerinin oranı \% 5'dir. Katılımcıların genellikle kadın ve evli bireylerden oluştuğu görülmektedir. Eğitim durumları itibariyle ise $\% 42$ 'sinin lise ve dengi okul mezunu olduğu ve \% 50'sinin ise üniversite mezunu olduğu belirlenmiştir. \% 8'lik bir grup ise çeşitli eğitim düzeylerine sahiptir.

\subsection{Araştırma Değişkenlerinin Ortalama Değerleri}

Araştırma değişkenlerinin ortalama değerleri incelendiğinde çalışanların daha ziyade önleyici odağa sahip oldukları görülmektedir. Sapkın davranışlar, ödül odak ve arkadaşları tarafından dışlanma ortalamanın altındadır. Yöneticileri tarafından dışlanmanın da ortalamanın üzerinde olduğu görülmektedir. Ayrıca yönetici tarafından dışlanma arkadaşları tarafından dışlanmadan daha yüksek düzeyde görünmektedir.

Tablo 1: Araştırma Değişkenlerinin Ortalama Değerleri ve Standart Sapmaları

\begin{tabular}{lcc}
\hline & Ort. & S. \\
\hline Örgütsel dışlanma & 2.36 & 0.88 \\
Arkadaşları tarafından dışlanma & 2.19 & 1.02 \\
Yöneticileri tarafından dışlanma & 3.19 & 0.92 \\
Önleyici odak & 3.50 & 0.91 \\
Ödül odak & 2.61 & 0.92 \\
Sapkın davranışlar & 1.93 & 0.96 \\
\hline
\end{tabular}

\subsection{Araştırma Değişkenleri Arasındaki İlişkiler}

Araştırma değişkenleri arasındaki ilişkiler aşağıda yer alan Tablo 2'deki korelasyon matrisinde gösterilmiştir.

Tablo 2: Korelasyon Matrisi

\begin{tabular}{lcccccc}
\hline & 1 & 2 & 3 & 4 & 5 & 6 \\
\hline 1. Arkadaşları tarafından dışlanma & 1.00 & & & & & \\
2. Yöneticileri tarafından dışlanma & .114 & 1.00 & & & & \\
3. Toplam dışlanma & $0.699^{* *}$ & $0.791^{* *}$ & 1.00 & & & \\
4. Önleyici odak & $0.393^{* *}$ & $-0.250^{* *}$ & $-0.273^{* *}$ & 1.00 & & \\
5.Ödül odak & $-0.152^{* *}$ & $0.368^{* *}$ & $0.507^{* *}$ & $-0.266^{* *}$ & 1.00 & \\
6. Sapkın davranışlar & $0.195^{* *}$ & $0.270^{* *}$ & $0.314^{* *}$ & $0.225^{* *}$ & $-0.157^{* *}$ & 1.00 \\
\hline
\end{tabular}

${ }^{* *} \mathrm{p}<0.01$

Değişkenler arası korelasyonlar incelendiğinde dışlanmanın genel olarak sapkın davranışlar ile negatif yönde anlamlı ilişkilere sahip olduğu görülmektedir. Önleyici odak ile ödül odak arasında negatif yönlü anlamlı ilişki bulunmaktadır $(r=-0.266, \mathrm{p}<0.01)$. Önleyici odak ile sapkın davranışlar arasında pozitif yönlü $(r=0.225$, 
$\mathrm{p}<0.01)$, ödül odak ile sapkın davranışlar arasında negatif yönlü anlamlı bir ilişki bulunmaktadır $(\mathrm{r}=-0.157$, $\mathrm{p}<0.01)$.

\subsection{Dışlanmanın Sapkın Davranışlar Üzerindeki Etkisinde Önleyici Odağın Aracılık Rolü}

Önleyici odağın aracılık rolünü belirleyebilmek için aracılık etkisini test edecek bir analiz yapılmıştır. Baron ve Kenny (1986:1176) tarafından önerilen aracı değişken analizi yöntemine göre bir değişkenin aracı rolü üstlenebilmesi için şu koşulların var olması gerekmektedir:

- Bağımsız (öncül) değişken aracı değişkenle anlamlı bir ilişki içerisinde olmalıdır (a),

- Bağımsız (öncül) değişken bağımlı değişkenle anlamlı bir ilişki içerisinde olmalıdır (c),

- Aracı değişken bağımlı değişken arasında anlamlı bir ilişki bulunmalıdır (b),

- Bağımsız değişkenin bağımlı değişken üzerindeki etkisi, aracı değişken devreye girdiğinde azalmalı ya da tamamen ortadan kalkmalıdır. Bu etkinin tamamen ortadan kalkması tam aracilık ilişkisinin; tamamen ortadan kalkmaması ise kısmi aracılık ilişkisinin yani başka aracı değişkenlerinde varlığına işaret etmektedir.

Analizin yapılabilmesi için tüm değişkenler arasında ilişki bulunması gerekliliği anlaşılmaktadır. Korelasyon matrisi incelendiğinde gerekli olan tüm ilişkilerin bulunduğu görülmüştür. Bu bakımdan analiz yapılabilir. Analiz sonuçları şu şekildedir:

Tablo 3: Aracilık Analizi

\begin{tabular}{|c|c|c|c|c|}
\hline Model & Std Beta & Adj. $R^{2}$ & SE & Sig \\
\hline $\begin{array}{l}\text { Model 1 } \\
\text { Arkadaşları tarafından dışlanma } \rightarrow \text { İşyerinde sapkın } \\
\text { davranış }\end{array}$ & 0.195 & 0.034 & 1.06 & 0.000 \\
\hline Önleme odak $\rightarrow$ İşyerinde sapkın davranış & 0.225 & 0.047 & 1.06 & 0.000 \\
\hline Arkadaşları tarafından dışlanma $\rightarrow$ önleme odak & 0.393 & 0.151 & 0.84 & 0.000 \\
\hline $\begin{array}{l}\text { Arkadaşları tarafından dışlanma } \rightarrow \text { işyerinde sapkın } \\
\text { davranış /önleme odak (Aracı) }\end{array}$ & 0.144 & 0.139 & 1.00 & 0.000 \\
\hline $\begin{array}{l}\text { Model } 2 \\
\text { Arkadaşları tarafından dışlanma } \rightarrow \text { işyerinde sapkın } \\
\text { davranış }\end{array}$ & 0.195 & 0.034 & 1.06 & 0.000 \\
\hline Ödül odak $\rightarrow$ işyerinde sapkın davranış & -0.157 & 0.025 & 1.07 & 0.000 \\
\hline Arkadaşları tarafından dışlanma $\rightarrow$ ödül odak & -0.152 & 0.020 & 0.92 & 0.011 \\
\hline $\begin{array}{l}\text { Arkadaşları tarafından dışlanma } \rightarrow \text { işyerinde sapkın } \\
\text { davranış/ödül odak (Aracı) }\end{array}$ & 0.188 & 0.067 & 1.05 & 0.001 \\
\hline $\begin{array}{l}\text { Model } 3 \\
\text { Yöneticileri tarafından dışlanma } \rightarrow \text { işyerinde sapkın } \\
\text { davranış }\end{array}$ & 0.270 & 0.069 & 1.04 & 0.000 \\
\hline Önleme odak $\rightarrow$ işyerinde sapkın davranış & 0.225 & 0.047 & 1.06 & 0.000 \\
\hline Yöneticileri tarafından dışlanma $\rightarrow$ önleme odak & 0.368 & 0.132 & 0.85 & 0.000 \\
\hline $\begin{array}{l}\text { Yöneticileri tarafından dışlanma } \rightarrow \text { işyerinde sapkın } \\
\text { davranış /önleme odak (Aracı) }\end{array}$ & 0.220 & 0.188 & 0.98 & 0.000 \\
\hline
\end{tabular}




\begin{tabular}{|l|l|l|l|l|}
\hline $\begin{array}{l}\text { Model } 4 \\
\text { Yöneticileri tarafından dışlanma } \rightarrow \text { işyerinde sapkın } \\
\text { davranış }\end{array}$ & $\mathbf{0 . 2 7 0}$ & 0.069 & 1.04 & 0.000 \\
Ödül odak $\rightarrow$ işyerinde sapkın davranış & -0.157 & 0.025 & 1.04 & 0.000 \\
Yöneticileri tarafından dışlanma $\rightarrow$ ödül odak & -0.250 & 0.059 & 0.90 & 0.000 \\
$\begin{array}{l}\text { Yöneticileri tarafından dışlanma } \rightarrow \text { işyerinde sapkın } \\
\text { davranış /ödül odak (Aracı) }\end{array}$ & $\mathbf{0 . 2 0 1}$ & 0.120 & 1.02 & 0.000 \\
\hline
\end{tabular}

Önleme ve ödül odağın aracılık rolünün gösterildiği yukarıdaki tablo incelendiğinde hem ödül hem de önleme odağın anlamlı aracılık etkisine sahip olduğu ve aracılık etkisinin kısmi olduğu görülmektedir. Tüm modellerde birinci eşitlikle dördüncü eşitlikteki beta katsayılarına bakıldığında kısmi aracılık etkisi anlaşılmaktadır. Bu sonuçlara göre, örgütlerde dışlanmanın bireylerde sapkın davranışları artırmasında ödül ve önleyici odağın anlamlı bir azaltıcı etkisi bulunmaktadır.

\section{Sonuç ve Tartışma}

Bu çalışmada örgütsel dışlanmanın bireylerin sapkın davranışları üzerindeki etkisi ve bu etkide düzenleyici odağın aracılık rolü ele alınmıştır. Düzenleyici odak, ödül ve önleyici odak olmak üzere iki alt boyutta incelenmiştir. Örgütsel dışlanma da arkadaşları tarafından dışlanma ve yöneticileri tarafından dışlanma olarak iki alt boyutta incelenmiştir. Çalışma Türkiye'de Kayseri ilinde sağlık sektörü çalışanları ile gerçekleştirilmiştir.

Araştırmanın ilk sonucu arkadaşları veya yöneticileri tarafından dışlanan bireylerin sapkın davranışlar sergilemesidir. Her iki dışlanma türünde de bireyler sapkın davranış sergileme eğilimine girmektedir. Gerek intikam alma gerekse negatif psikolojiye sahip olma nedeniyle bireyler istenmeyen davranışlar sergilemektedir. Bu durum alanyazındaki araştırmalarla uyumlu ve beklenen bir sonuçtur. Çünkü ait olmaktan ve sosyal etkileşimden mahrum bırakılan insanların bu durumdan olumsuz yönde etkilendikleri ve bu duruma karşı tepki niteliğinde davranışlara yöneldikleri bilinmektedir (Braas ve Scott, 2007:3; Hitlan ve Noel, 2009. 479; Hitlan vd., 2006: 218).

Araştırmanın ikinci sonucu dışlanma ile ödül odak arasındaki pozitif, dışlanma ile önleme odak arasındaki negatif ilişkidir. Bu beklenen bir sonuç değildir. Dışlanma arttıkça önleme odağın da artması, yani aralarında pozitif bir ilişkinin olması beklenirdi. Çünkü dışlanan bireyin, diğerlerine güvenmemeye dayalı olarak kendini güvenceye almak için olumsuz sonuçları önlemeye çalışması beklenirdi. Ancak bu yaklaşım mevcut işyerinde çalışmaya devam etme eğilimi olan kişiler için geçerlidir. İşten ayrılmayı göze almış bir çalışan dışlanmaya karşı güçlü bir tepki oluşturarak işyerinin kurallarını ve performans ölçütlerini umursamayabilir. Böylece dışlanma arttıkça önleme odak azalabilir. Diğer taraftan dışlanma ile ödül odak arasındaki pozitif ilişki de beklenen bir sonuç değildir. Dışlanan bireyin olumsuz duygular yaşamasından dolayı heves ve heyecanla amaçlarına odaklanması beklenmez (Hitlan ve Noel, 2009: 479). Fakat böyle durumlarda bireysel farklılıkları da hesaba katmak gerekir. Bazı insanlar ne kadar çok olumsuzluk yaşasalar da olumlu düşünmeye ve amaçlarının peşinden koşmaya devam etmektedir. Ayrıca kişinin gerçekleştirmek için gayret gösterdiği amaçlar işyerinin ulaşılmasını istediği amaçlar değil, kişisel amaçları olabilir. Bu durumda dışlanma, kişinin kendi amaçlarına odaklanmasını artırabilir. Alanyazında bu kavramlar arasındaki ilişkilerin değerlendirildiği bir çalışmaya ulaşılamamıştır. Dolayısıyla bu çalışmada ulaşılan sonuçların diğer çalışmalarla kıyaslanması mümkün olmamıştır.

Araştırmanın üçüncü sonucu önleme odağın sapkın davranışlar üzerindeki pozitif etkisidir. Önleme odağına sahip bireyler daha fazla sapkın davranış sergileme eğilimindedirler. Bu sonuç da dikkate değer bir sonuçtur. Çünkü önleme odağına sahip bireyler bir taraftan sorun çıkmaması için azami derecede gayret gösterirken diğer taraftan sapkın davranışlar sergilemektedirler. Önleme odağı yüksek bireylerin negatif duygular içerisinde olmaları sapkın davranışların ortaya çıkmasına katkı sağlamış olabilir. Ödül odağına sahip bireylerde ise tam tersi bir durum söz konusudur. Ödül odağı, bireylerin negatif davranışlar sergilemesini önlemektedir. Bu sonuç da ödül odağı yüksek bireylerin olumlu duygular içerisinde olmaları ile açıklanabilir. 
Ödül odaklı yaklaşımın, engelleme odaklı yaklaşıma kıyasla, ulaşılmaya çalışılan unsurlara yönelik olarak pozitif tutumların gelişmesine daha fazla katkı sağladığı bilinmektedir. Bu bakımdan bu sonuç şaşırtıcı bir sonuç değildir.

Araştırmanın dördüncü sonucu hem önleme hem de ödül odağın anlamlı bir aracılık etkisine sahip olmasıdır. Yöneticileri veya arkadaşları tarafından dışlanan bireylerde sapkın davranışlarda bir artış görülmektedir. Önleme ve ödül odak bu etkiyi azaltmaktadır. Etkinin bir kısmını üzerine almaktadır. Dolayısıyla araştırmadaki temel soru cevaplandırılmış ve hipotez doğrulanmıştır. Araştırmanın beşinci sonucu arkadaşları tarafından dışlanan bireylerde ödül odağın azalması, yöneticileri tarafından dışlanan bireylerde ise ödül odağın artmasıdır. Üzerinde ayrıntılı olarak çalışılması gereken bir sonuçtur bu. Arkadaşları tarafından dışlanan birey olumlu sonuçlar üretmeyi bir kenara bırakmakta ve arkadaşlarına tepki göstermektedir. Yöneticileri tarafından dışlanan bireyler ise işlerini kaybetmemek için, bazı yönetsel uygulamalardan ayrı tutulmamak için ödül odağını artırmaktadır. Benzer bir durum önleme odağı için de geçerlidir. Arkadaşları tarafından dışlanan bireyler önleme odaklarını artırmakta ve daha fazla olumsuz sonucun ortaya çıkmasını önlemeye çalışmaktadırlar. Yöneticileri tarafından dışlanan bireyler ise önleyici odaklarını azaltarak kabullerini artırmaya çalışmaktadırlar. Aslında her iki sonuç birbirini doğrular niteliktedir. Korelasyon matrisinde önleme odak ile ödül odak arasındaki negatif yönlü ilişki de zaten bu durumu teyit etmektedir.

Alanyazında, dışlanma, sapkın davranış ve düzenleyici odak konularını birlikte ele alan bir çalışma bulunmadığından elde edilen sonuçların kıyaslanması mümkün olmamıştır. Bu konuda başka çalışma yapılırsa araştırma sonuçlarının kıyaslanması sağlanabilir.

Araştırma sonuçları hem ödül hem de önleme odağın anlamlı aracılık etkisi olduğunu göstermiştir. Düzenleyici odak örgütsel dışlanmanın bireylerin sapkın davranışları üzerindeki olumsuz etkisini azaltmaktadır. Sonraki çalışmalarda, bu sonuçlar derinlemesine analiz edilmelidir. Gerek örneklem değiştirilerek, gerekse ölçekler değiştirilerek başka çalışmalar yapılmalıdır. Kültürel farklılıkları dikkate alan çalışmalar da bu sonuçların anlaşılmasını kolaylaştırabilir.

\section{KAYNAKÇA}

Baron, Reuven. M. ve Kenny, David A. (1986). The moderator-mediator variable distinction in social psychological research: Conceptual, strategic, and statistical considerations, Journal of Personality and Social Psychology, 51, 1173-1182.

Baumeister, Roy F., Dewall, C. Nathan, Ciarocco, Natalie J. ve Twenge, Jean M. (2005). Social exclusion impairs self-regulation, Journal of Personality and Social Psychology, 88, 589-604.

Braas Daniel J. ve Scott Kristin D. (2007). The development and test of an exchange-based model of interpersonal workplace exclusion, Doctorate Thesis, University of Kentucky.

Brenninkmeijer, V., Demerouti, E., Blanc, Le, Pascale M., ve Emmerik, Van, I. J. Hetty (2010). Regulatory focus at work: The moderating role of regulatory focus in the job demands-resources model, Career Development International, 15, 708-728.

Brown, Michael E. ve Trevino, Linda K. (2006). Socialized charismatic leadership, values congruence, and deviance in work groups, Journal of Applied Psychology, 91, 954-962.

Dunlop, Patrick D. ve Lee, K. (2004). Workplace deviance, organizational citizenship behavior, and business unit performance: The bad apples do spoil the whole barrel, Journal of Organizational Behavior, 25, 6780.

Elsamen, A. A. (2011). Examining the construct validity of the lockwood goal orientation scale using the general hierarchal model: An exploratory study, Journal of Management Policy and Practice, 12(4), 81-92.

Hitlan, Robert T., Cliffton, Rebecca J. ve Desoto, M. Catherine (2006). Perceived exclusion in the workplace: The moderating effects of gender on work-related attitudes and psychological health, North American Journal of Psychology, 8, 217-235. 
Hitlan, Robert T. ve Noel, J. (2009). The influence of workplace exclusion and personality on counterproductive work behaviours: An interactionist perspective, European Journal of Work and Organizational Psychology, $18,477-502$.

Huffman, K. (1994). Psychology in Action, Canada: John Wiley.

Oyserman D., Uskul A. K., N. Yoder, Randy M. Nesse ve D. R. Williams. (2007). Unfair treatment and selfregulatory focus, Journal of Experimental Social Psychology, 43, 505-512.

Raelin, Joseph A. (1994). Three scales of professional deviance within organizations, Journal of Organizational Behavior, 15, 483-501.

Robinson, Sandra L. ve Bennett, Rebecca J. (1995). A typology of deviant workplace behaviors: A multidimensional scaling study, Academy of Management Journal, 38, 555-72.

Scott, K. D. ve Brass, Daniel J. (2007). The development and test of an exchange-based model of interpersonal workplace exclusion, Doctorate Thesis, University of Kentucky.

Uskul A. K., Sherman David K. ve Fitzgibbon, J. (2009). The cultural congruency effect: Culture, regulatory focus, and the effectiveness of gain- vs. loss-framed health messages, Journal of Experimental Social Psychology, 45, 535-541.

Witt, L. A. ve Andrews, Martha C. (2006). The predisposition to engage in interpersonal deviance at work, Academy of Management Annual Meeting Proceedings, 1-6.

Wu, C., Mcmullen, J. S., Neubert, Mitchell J., ve YI, Xiang (2008). The influence of leader regulatory focus on employee creativity, Journal of Business Venturing, 23, 587-602.

Yperen, Nico W. V. (2003). On the link between different combinations of negative affectivity and positive affectivity and job performance, Personality and Individual Differences, 35, 1873-1881. 